\title{
UN-ACCOUNTABLE?: A RESPONSE TO DEVIKA HOVELL
}

\author{
Rosa Freedman*
}

\section{Introduction}

Devika Hovell has provided an excellent call to arms for academics to move beyond the question of whether the United Nations has due process deficiencies: By now we all know that it does. She invites us to focus instead on making "the normative case for adopting due process safeguards in UN decision making," insisting that until now scholars have failed to ask the important theoretical questions underpinning their policy research. ${ }^{1}$ Hovell uses two case studies to demonstrate why resort to judicial mechanisms ought not to be the answer when seeking to find ways to ensure due process. She first focuses on targeted sanctions and then turns attention to cholera in Haiti.

While I agree with the normative conclusions in this article, and agree that there ought to be greater focus on theory, in this short piece I shall make several points that demonstrate that the Haiti case study is more complex than Hovell's account suggests.

\section{Accountability Mechanisms for Peacekeeping}

The starting point in my response to Hovell's article is that some of the unintended consequences of peacekeeping - specifically harms, injuries, and losses — have been and continue to be dealt with through the accountability methods that Hovell identifies. There are two different forms that accountability methods take depending on the scale of harms caused. At the level of individual harms there is a special regime on liability for harms caused to third parties, which usually is implemented through local claims review boards. ${ }^{2}$ These boards within peacekeeping missions address loss, harm, or injury to individuals caused by peacekeeping personnel. Larger scale harms, often with mass victims, typically have resulted in public inquiries through the form of UN-appointed panels of experts that investigate and then provide recommendations for the United Nations to implement. While information-gathering, answerability and responsiveness vary in form between those mechanisms, accountability provides the normative foundations of both approaches to addressing the harms caused.

I first turn to the local claims review boards. Hovell and other commentators rightly point to the Model SOFA provision for a standing claims board ${ }^{3}$ and question why such a board has not been established in any peacekeeping mission other than Kosovo. Despite that failure, peacekeeping missions have found other ways to resolve disputes that do not resort to judicial mechanisms but that still ensure due process. It is standard

\footnotetext{
* Senior Lecturer at Birmingham Law School.

Originally published online 22 July 2016.

${ }^{1}$ Devika Hovell, Due Process in the United Nations, 110 AJIL 1, 2 (2016).

${ }^{2}$ GA Res. 52/247 (July 17, 1998).

${ }^{3}$ Model Status of Armed Forces Agreement for Peace-Keeping Missions, UN Doc. A/45/594, para. 51 (Oct. 9, 1990).
} 
practice for UN peacekeeping missions to set up local claims review boards or to have other forms of dispute resolution mechanisms (such as good offices, mediation, or others) in accordance with Section 29 of the Convention of Privileges and Immunities of the United Nations. The decisions of those local claims review boards may be challenged by requests for further administrative review within the United Nations or by arbitration. The information-gathering, answerability, and responsiveness of those mechanisms largely occur through quasijudicial methods such as evidence presented to the boards, reports, and the allocation of remedies where appropriate.

The other main way in which accountability occurs is through UN-appointed panels of experts that conduct independent inquiries into harms caused by peacekeeping personnel. Such harms include failures to protect civilians from genocide and sexual abuse. The panels are a form of public inquiry to gather information, ensuring participation of interest groups. The answerability comes in the form of reports, including recommendations that are the basis of responsiveness. Crucially, those reports frequently lead to apologies or expressions of regret, a key element highlighted by Hovell. They have also led to reforms of policies and processes aimed at preventing future harms, and to the implementation of other recommendations contained within the reports.

\section{Failures of Existing Mechanisms}

The existing mechanisms for addressing harms caused by peacekeeping personnel are not perfect-far from it. Indeed, in some areas they need a radical overhaul. This is a main reason why Hovell's focus on only the normative foundations of due process is insufficient: We also need to focus on the existing mechanism and analyse their flaws empirically. Radical overhaul of the UN's due process mechanisms will require scholars to focus on practical issues as well as theoretical ones.

A key problem with the existing dispute resolution mechanisms at the micro level is that the United Nations sits as judge and jury over itself, which is problematic when claims by external parties are brought against individuals operating under the UN umbrella, or against the organization itself. That issue has also been raised in relation to its internal employment tribunals and other similar mechanisms for dealing with disputes. The value of accountability is in tension with the need for the United Nations to have immunities in order to fulfil its functions when operating in Member States. A related problem, and one that has been at the centre of the Haiti Cholera Claims, is that the United Nations determines whether a particular mechanism is available to resolve a particular dispute. In terms of Haiti and cholera, the United Nations prevented its mechanisms from being used to resolve that dispute (to which we shall turn in the next section).

The issue of how the United Nations deals with mass harms caused by peacekeeping personnel is also problematic. The reports that are produced do not always result in changes made at the policy level, and even where they do, not all recommendations are followed. Recommendations of panels appointed to look at sexual abuse and exploitation (e.g. the Zeid Report in $2005^{4}$ and the more recent Deschamps Report in $2015^{5}$ ), for example, have largely been watered down or altogether blocked either by the Secretariat or by Member States. The reports on Rwanda (1999), ${ }^{6}$ Srebrenica (1999), ${ }^{7}$ and the Brahimi Report ${ }^{8}$ the following

\footnotetext{
${ }^{4}$ Letter dated 24 March 2005 from the Secretary-General to the President of the General Assembly, UN Doc. A/59/710 (Mar. 24, 2005).

${ }^{5}$ Marie Deschamps et al., Taking Action on Sexual Exploitation and Abuse by Peacekeepers (Dec. 17, 2015).

${ }^{6}$ Letter dated 15 December 1999 from the Secretary-General addressed to the President of the Security Council, UN Doc. S/1999/1257 (Dec. 16, 1999).

${ }^{7}$ Secretary-General, Report pursuant to resolution 53/35, The fall of Srebenica, UN Doc. A/54/549 (Nov. 15, 1999).
} 
year led to significant changes in terms of responsibility to protect civilians, but those lessons were not absorbed by all UN staff and the recent report on Sri Lanka (2011) highlighted continued failures of the United Nations to protect civilians from genocide. ${ }^{9}$

Despite adhering to the normative values that Hovell has set out, the existing mechanisms are flawed. And that is even in relation to something as straightforward — or relatively so-as Haiti and cholera. In many ways the Haiti Cholera Claims ${ }^{10}$ are easier to resolve through existing mechanisms than other types of harms. Local claims review boards, for example are better able to provide redress to civil harms caused by troops than they are criminal issues. And yet criminal responsibility is a crucial aspect of accountability. This has been particularly problematic in relation to sexual abuse and exploitation, as many of the perpetrators are soldiers rather than civilians. Those troops are under the exclusive jurisdiction of their sending states, and therefore any criminal liability rests with their home country. But that is a separate issue, ${ }^{11}$ and one that I only raise here to demonstrate the complexities and complications of adopting a "one size fits all" approach to these matters.

Returning to Haiti and cholera, Hovell insists that the failures in relation to UN accountability have occurred because of the victims' resort to judicial mechanisms. She seems to have glossed over the fact that the victims sought, and were denied, access to the existing but flawed alternative dispute resolutions mechanisms. I argue that it is not the lack of mechanisms that is at issue, but rather the UN's refusal to use those mechanisms. It is to that broader issue-of the differing reliance on accountability mechanisms in different problem cases - that we shall now turn, because the Haiti cholera victims are like the modern-day David against the proverbial Goliath in their fight to hold the United Nations accountable for the cholera epidemic that began in 2010 and still is ongoing.

\section{Haiti, Cholera, and Accountability}

Hovell insists that resort to judicial mechanisms ought always to occur only where there are no alternative options available. She notes that the lawyers in the Haiti Cholera Claims are on record as saying that they felt they had no other venue when they filed claims in the New York District Court. But what is missing from this and other analyses of the claims is that the lawsuit in the United States was part of an advocacy strategy aimed at keeping the cholera issue live and ensuring that it did not become lost in the very many problems that Haiti and Haitians experience. That strategy clearly has achieved its aims. The Haiti Cholera Claims brought attention to a situation that largely had flown under the radar of the international community, the legal community, the media, and the wider public. Not only has this litigation succeeded in bringing attention to the issue, but it has also succeeded in bringing forward other possibilities for resolution.

To evaluate judicial resolution we must look beyond just the form and understand the benefits, which in this case includes raising the profile of the underlying problem and giving coherence to a social movement for justice. It is important to understand both the chronology ${ }^{12}$ and the reasons why the claims were filed,

\footnotetext{
8 Secretary-General, Identical Letters dated 21 August 2000 to the President of the General Assembly and the President of the Security Council, UN Doc. A/55/305-S/2000/809 (Aug. 21, 2000).

${ }_{9}$ Marzuki Darusman et al., Report of the Secretary-General's Panel of Experts on Accountability in Sri Lanka (Mar. 31, 2011).

${ }_{10}$ Much has been written about the Haiti Cholera Claims, a selection of which (from different angles) is as follows: Jose Alvarez, The United Nations in the Time of Cholera, AJIL Unbound (April 4, 2014, 12:01 pm); Kristen Boon, The United Nations as Good Samaritan: Immunity and Responsibility, 16 CHI. J. INT'L L. 341 (2015); Rosa Freedman \& Nicolas Lemay-Hebert, 'Jistis ak reparasyon pou tout viktim kolera MINUSTAH': The United Nations and the Right to Health in Haiti, 28 Leiden Journal of International Law 507 (2015); Frédéric Mégret, La responsabilité des Nations Unies aux temps du cholera, 47 Revue Belge de Droit International 161 (2013).

${ }^{11}$ For information and resources about the issue of sexual violence, peacekeeping and accountability, see the Code Blue Campaign.

${ }^{12}$ Expert Workshop on Resolving the Cholera Crisis in Haiti, UNIVERSITY OF BIRMINGHAM.
} 
first with MINUSTAH ${ }^{13}$ and then at the New York District Court, before turning to how the claims have encouraged and enabled accountability mechanisms to be used in relation to Haiti and cholera.

Immediately following the introduction of cholera into Haiti in October 2010, questions were asked about how MINUSTAH would remedy the harms caused to the local population. In January 2011, the United Nations appointed a Panel of Experts to report on the situation. The UN Panel of Experts released its report in May 2011.14 The report argued that "the evidence overwhelmingly supports the conclusion that the Haiti cholera outbreak was due to contamination of the Meille Tributary of the Artibonite River with a pathogen strain of current South Asian type Vibrio cholerae as a result of human activity." It found that the sanitation conditions at the UN bases were not sufficient "to prevent fecal contamination of the Meille Tributary System of the Artibonite River."

In November 2011, approximately five thousand Haitians represented by the Burean des Avocats Internationaux and the Institute for Justice and Democracy in Haiti filed claims with MINUSTAH seeking: (1) compensation; (2) remediation through water and sanitation infrastructure; and (3) a formal admission of responsibility..$^{15}$ It is crucial to note that these claims did not focus solely on financial compensation, but rather on the range of responsiveness tools that Hovell discusses in relation to mass harms or atrocities. Indeed, they are based on the values that Hovell sets out and which draw upon Pablo de Greiff's broad conception of justice in relation to reparations. ${ }^{16}$ The claimants requested that MINUSTAH establish a standing claims commission to hear the claims in a fair and impartial manner, as called for by the SOFA. Of course, such a commission was unlikely to be established given the United Nations' failure to establish such commissions in almost every other peacekeeping mission. Yet there was an expectation that other alternative dispute resolution mechanisms would be offered, whether in the form of a local claims review board, arbitration, or some other mechanism.

The UN Legal Counsel acknowledged receipt of the claims in December 2011, but in February 2013 the UN Legal Counsel sent a letter to the attorneys representing the claimants stating that the claims were "not receivable" because they "would necessarily include a review of political and policy matters." In May 2013 the attorneys representing Haitian claimants responded to the UN Legal Counsel's letter requesting (1) a meeting with the UN's Office of Legal Affairs; (2) the engagement of a mediator; and/or (3) the establishment of a standing claims commission as required by the SOFA. Those requests were refused by the UN Legal Counsel in July 2013.

The United Nations' refusal to use alternative dispute resolution mechanisms and the lengthy delays in responding to the Panel of Experts' recommendations and to the claims filed with MINUSTAH put the claimants in a difficult position. Almost three years after the epidemic began, and with independent scientific reports ${ }^{17}$ and an additional article from the Panel of Experts ${ }^{18}$ all confirming that UN peacekeepers had introduced cholera into Haiti, inadequate steps had been taken to contain or eradicate the disease, let alone to provide any other forms of reparations. ${ }^{19}$ At that stage, the victims filed a lawsuit based on U.S. tort law in the New York District Court. Hovell presents the reliance on tort law as deeply problematic from both a theoretical and practical perspective. She also seeks to demonstrate that the use of courts was inappropriate for this

${ }^{13}$ United Nations Stabilization Mission in Haiti (Minustah).

${ }^{14}$ Alejandro Cravioto et al., Final Report of the Independent Panel of Experts on the Cholera Outbreak in Haiti.

15 Petition for Relief, Institute For Justice \& Democracy in Haiti.

16 Pablo de Greiff, Justice and Reparations, in The Handbook of Reparations 451 (Pablo de Greiff ed., 2006).

${ }^{17}$ Renauld Piarroux et al., Understanding the Cholera Epidemic, Haiti, 17 EMERGING InFECTIOUs DisEASES 1161 (2011).

18 Daniele Lantagne et al., The Cholera Outbreak in Haiti: Where and How did it begin?, in CHOLERA OutBreAKs (G. Balakrish Nair \& Yoshifumi Takeda eds., 2014).

${ }^{19}$ Freedman \& Lemay-Hebert, supra note 10. 
case, but without having explored the UN resistance to other dispute mechanisms and the lack of UN political will to resolve the claims. When viewed in context of the previous significant efforts to resolve the dispute through traditional and less problematic methods, it becomes clear why the claims were filed. While Hovell views adjudication as a last resort, she fails to take into account that the availability, let alone use, of other mechanisms - at least within this context—depend on the United Nations' political will, which simply has not existed in relation to the Haiti cholera claims.

The claims filed in the New York District Court, now at the appeals stage, have resulted in widespread coverage of the cholera situation through op-eds and television coverage across the United States, Canada, France, and the United Kingdom. ${ }^{20}$ The claims have also brought the situation to the attention of UN staff and Member States that previously had no knowledge about Haiti and cholera. The strategy of "lawfare"using courts as an advocacy tool to achieve a result outside of the courtroom-has enabled the attorneys representing the claimants to garner broad sympathy for the claimants and their fight to hold the United Nations accountable. That support has come from a range of individuals, including current and former UN staff, Member States, jurists, and academics, some of whom signed amici briefs and others of whom have provided support in less public ways. While there may not be widespread support for the claims succeeding, owing to widespread recognition that UN immunity is crucial for future peacekeeping operations, the interest that the case has brought has resulted in steps being taken towards finding alternative ways to resolve this dispute.

\section{Concluding Remarks}

The points that I have raised in this short piece are not aimed at undermining Hovell's argument, but at demonstrating how aspects of her normative case for due process in UN decision-making already exist within current mechanisms for resolving disputes arising from peacekeeping. Hovell is right in her call to arms for academics to move beyond the "j'accuse moment" and that there should be discussion about the normative case for due process in decision-making. But I disagree that we ought to focus solely on finding a rich theoretical approach to these issues rather than discussing the mechanisms and procedures that already exist. As academics, we have more than one job to do in this area, not least because the normative approach that Hovell advocates already underpins the existing architecture. Rather than starting from scratch, we must focus on and address the flaws in the existing mechanisms and in the system as a whole in order to give effect to due process in UN decision-making on peacekeeping disputes. There is sufficient scope for both normative and empirical work on these sorts of questions. The challenge is to ensure that the two are engaged in fruitful exchanges that are beneficial at the theoretical and practical levels.

${ }^{20}$ Delama Georges v. United Nations, Brief for Appellants, 15-455-cv (2d Cir., May 27, 2015). 